\title{
Comparison of the Motivation and Learning Strategies of Brunei Secondary Students in Forms 1-5 (Years 7-11): Implications for Teaching
}

\section{Lawrence Mundia}

Assoc. Prof., corresponding author, Universiti Brunei Darussalam, Brunei, lawrence.mundia@ubd.edu.bn

Rosmawijah Jawawi

Universiti Brunei Darussalam, Brunei, rosmawijah.jawawi@ubd.edu.bn

Malai Hayati Sheikh Abdul Hamid

Universiti Brunei Darussalam, Brunei, hayati.hamid@ubd.edu.bn

Nordiana Zakir

Universiti Brunei Darussalam, Brunei, nordiana.zakir@ubd.edu.bn

\begin{abstract}
This field survey had two main objectives. First, to determine the differences in the participants' Motivated Strategies Learning Questionnaire (MSLQ) scores by gender, age, educational level, and school attended. Second, to identify patterns of the differences emerging from the research outcomes. Using a simple random sample of 310 Brunei Secondary Students in Forms 1-5 (Years $7-11,174$ females, drawn from three schools), the study compared and contrasted the participants' performance on the MSLQ. Females scored higher on seven of the 15 variables including test anxiety. Altogether, 41 significant differences were obtained by gender, age, education, and school across 11 subscales. However, no significant differences were found on four variables (self-efficacy, task value, elaboration, and peer learning). The highest scorers on external motivation were females, 12-year-olds, Year 10s, and students in School 1. Rehearsal and effort regulation were most predominant in Year 7s, Year 9s, and students in School 1. In contrast, critical thinking was more prevalent in Year 11s and students in Schools 1 and 2. The highest number of significant differences involved effort regulation and many differences in this variable were also the strongest $(\mathrm{p}<.01)$. Implications are discussed and further mixed-methods research using a larger sample, interview probes, and robust statistics such as confirmatory factor analysis was recommended.
\end{abstract}

Keywords: educational psychology, motivation, learning strategies, secondary school, Brunei

\section{INTRODUCTION}

In the context of the present study, motivation is mostly an inner drive to succeed in school or life (Dweck, 1999). McKean (1994) believed that individuals who lose their motivation for some reason(s) tend to procrastinate and feel helpless. Also, the more effective the learning strategies adopted by the students, the higher the student academic performance (Simsek and Balaban, 2010). Given this, the current study focused on motivation and learning pursuits as measured by the Motivated Strategies Learning Questionnaire, MSLQ (Pintrich, Smith, García, \& McKeachie, 1991a, b; 1993) at the secondary stage of education in Brunei government non-religious schools. The MSLQ includes motivation and learning strategies. Motivational strategies measure internal and external orientations, task value, control of learning beliefs, self-efficacy for learning and performance, and test anxiety. In

Citation: Mundia, L., Jawawi, R., Hamid, M. H. S. A., \& Zakir, N. (2021). Comparison of the motivation and learning strategies of brunei secondary students in forms 1-5 (Years 7-11): Implications for teaching. Anatolian Journal of Education, 6(2), 173-192. https://doi.org/10.29333/aje.2021.6213a 
learning strategies, the MSLQ assesses the constructs of rehearsal, elaboration, organization, critical thinking, and metacognitive self-regulation. Literature about the subscales of this instrument is reviewed below. The rationale and justification for investigating the educational motivations and learning strategies of Brunei secondary students have risen from challenges to both teachers and students brought by five main events or factors: (1) implementation of the inclusive education reforms in the 1990s; (2) introduction of the ongoing curriculum and assessment reforms effective from 2008; (3) changes to initial or preservice teacher education policy since 2009 to support the existing curriculum and assessment reforms; (4) unique opportunities posed to teachers and students by new types of student assessments; and (5) the need for instructors to embrace culturally sensitive practices when teaching.

\section{Literature Review}

\section{Intrinsic and extrinsic motivation, and task value}

Intrinsic motivation refers to the degree to which students recognize their drive to complete a task (Ryan and Deci, 2000). According to Ryan and Deci (2000), intrinsically motivated individuals tend to be guided by their inner goals and satisfaction from attaining the task rather than by external pressures or rewards from other people. Internally motivated students often engage in classroom activities, such as homework, examinations, or participation in class, because they naturally enjoy them, are curious, and feel challenged (Barry \& King, 2000). One factor that mediates internal motivation in a school or classroom setting is a supportive and conducive learning environment that makes learning enjoyable (Valerio, 2012). A supportive learning environment is an environment that is free from discrimination and bias but instead based on mutual respect, the involvement of social support from teachers and peers (Hinde-McLeod \& Reynolds, 2007). Another way for boosting inner motivation is instructors to be student-centered rather than teacher-centered and allow students part ownership of the learning process by permitting them to decide what they want to learn and how they can learn it (Scott, 2010; Valerio, 2012). However, learners must know the optimum amounts of their intrinsic motivation. Setting too high and unachievable tasks due to overconfidence might induce a dangerous sense of failure and demotivation (Sternberg \& Williams, 2000). The opposite of intrinsic motivation is extrinsic motivation which comes from sources outside the person such as encouragements, supports, and rewards from parents, teachers, and peers. However, extrinsic motivation is weaker compared to intrinsic motivation as it solely depends on external sources (Vansteenkiste, 2009). Some researchers suggest that external motivation should be replaced by self-efficacy (Lent et al., 1986 \& Multon et al., 1991) and an enhancement of a student's internal locus of control (Ackerman, 2018).

Pintrich et al. (1991b) defined task value as the importance and usefulness of skills to be acquired from learning to successfully perform a future desired or assigned task. According to Johnson et al. (2014) task value refers to the worthiness of knowledge and skills to be obtained from learning. The task value might be needed by both the person and others (Li et al., 2016). Researchers such as Pintrich (1999) and Yoon et al. (1996) found task value to be associated with academic achievement. Besides academic achievements and self-regulated skills, task value is highly associated with learning self-efficacy (Seo \& Taherbhai, 2009).

\section{Control of learning beliefs, self-efficacy, and test anxiety}

According to Manavipour and Saeedian (2016), the notion of control of learning beliefs refers to how much control the students possess to accomplish positive and desired outcomes. It reflects the individuals' estimated capability to perform and obtain the desired results. According to Rotter (1966), an individual's perceived locus of control (LOC) is one factor that may propel or doom the person to higher persistence and expectation of attaining the goal. Students tend to believe that control of their learning lies internally within them (internal LOC), or externally with others or the situation (external 
LOC). However, Rotter (1975) clarified his concept and explained that a child's belief and expectation that a particular behavior will bring a particular reinforcement is not the only predictor of the occurrence of that behavior. The value of the expected reinforcement is also important. A student who does not value a high grade, for example, may not study for a test, even though the student believes that the high grade is contingent on studying.

On the other hand, academic self-efficacy is a personal belief concerning the capacity or capabilities of an individual to perform a task and achieve the required results (Bandura, 1977; 1997). Many factors contribute to academic self-efficacy such as self-regulation, self-esteem, and motivation. Selfregulation refers to self-regulated thoughts, feelings, and actions that are planned and regularly modified to achieve personal goals thereby supplementing or complementing self-efficacy (Zimmerman, 2000; Pintrich, 2000). However, self-efficacy and self-regulation are still two different constructs as self-regulation involves a strategy for achieving learning goals while self-efficacy is the capability to succeed (Schunk \& Zimmerman, 2007). Neill (2005) defines self-esteem as the overall sense of value or worth of an individual as well as the extent to which others value, appreciate, or like that person. Lane, Lane, and Kyprianou (2004) claimed that self-efficacy could influence self-esteem when the success or failure of performing a task is attached to self-worth. Eccles, Wigfield, and Schiefele (1998) described motivation as the desire to achieve. Hence, self-efficacy and motivation are interrelated. Presumably, students with a higher level of motivation are also likely to have high selfefficacy.

Among students, tests play a crucial role in academic life (Orfus, 2008). The various assessments used to evaluate students cause a lot of anxiety in learners (Trifoni \& Shahani, 2011). Test anxiety appears to differ in intensity from subject to subject. Mathematics and statistics are said to be some of the most feared and anxiety-producing subjects in students (Onwuegbuzie \& Wilson, 2003; Onwuegbuzie, 2004). Statistics anxiety, especially, has many facets explained in detail by Onwuegbuzie (2004). The two main components of test anxiety are emotionality and worry (Culler, 1980; Cassady \& Johnson, 2002). Emotionality relates to the physiological reactions of anxiety such as nervousness while worry entails negative self-evaluations such as comparing oneself to peers and thinking of the consequences of failure. Test anxiety can have adverse effects on the performance and achievement of a student. Teachers should be aware of their students' test anxiety and procedures for reducing it (Trifoni \& Shahani, 2011).

\section{Rehearsal, elaboration, and organization}

Rehearsal helps students to overlearn the material and remember it longer. Research shows that students who frequently rehearse were most likely to succeed (Bıylklı \& Doğan, 2015). There are many ways in which rehearsal is done including underlining, copying text, highlighting important texts, making notes, repeating the subject matters, memorizing, reading aloud, summarizing and listing the concepts, and circling unknown words (Tay et al., 2016).

Elaboration refers to the process of clarifying, expanding, or building on the knowledge and skills a person already has. This enables students to maximize their learning and achievement (Somtsewu, 2008; Lynch, 2010). Elaboration is a deep cognitive processing strategy (Weinstein \& Mayer, 1986; Garcia, 1995). Common elaboration strategies include integrative and comparative techniques (Mayer, 1980).

Organization is the process of carefully rearranging points in a text according to their relationships and interrelations (Simsek \& Balaban, 2010). This improves the effective exposition of the points and clarity of expression thereby facilitating understanding of the written text (Gettinger \& Seibert, 2002). On the other hand, disorganized materials are difficult to understand and learn. 


\section{Critical thinking, metacognitive self-regulation, and time and study environment management}

Critical thinking is the ability to critique information when justified. It is an important skill that needs to be included in teacher education and school curricular (Huber et al., 2016; Shpeizer, 2018). Besides, it should also be incorporated into student assessment instruments (Shively et al., 2018). Critical thinking is positively related to self-efficacy (Hyytinen et al., 2018). Research suggests that innovative teaching practices, discovery learning, fostering creative behavior, and student-centered teaching help to promote critical thinking in students (Shively et al., 2018).

According to previous research (Dinsmore et al., 2008; Schunk \& Zimmerman, 2011), metacognitive self-regulatory activities include planning, monitoring, and regulating behaviors to enhance learning. Metacognitive self-regulation is said to have a significant impact on the academic performance of students (Sperling et al., 2004). One of how metacognitive self-regulation affects learning is that the learner engages in identifying self-related learning needs, goals, and materials including selecting, implementing proper strategies, and evaluating the learning outcomes (Hacker et al., 2009). This allows the learners to take a more self-directed and independent approach towards their learning (Dunn et al., 2012). Another way in which metacognitive self-regulation may affect learning is that it results in an increase of dialogic teaching within the classroom where metacognitive talk is encouraged (Labuhn et al., 2010). Metacognitive talk occurs when a person says out loud what they are thinking while they are carrying out a task (Whitebread, 2010). When students verbalize their inner thought processes, it helps to understand how to solve problems (Winne, 2011).

Time management refers to the ability to make use of one's time efficiently and productively (Macan, 1994). This helps to minimize procrastination and distraction. The management of the study environment refers to controlling the settings where students do their work (Leblebici, 2012). Ideally, the learner's study environment should be the same, organized, quiet, and relatively free of visual and auditory distractions. One of how the management of one's time and study environment affects learning is that it allows the learner to be more organized and productive (Akimoto et al., 2010). Maximizing one's preferences for time and study environment management improves one's productivity levels (Ajala, 2012).

\section{Effort regulation, peer learning, and help-seeking}

Effort regulation refers to the way people control their actions to achieve the self-proclaimed goals. This often involves examining and evaluating one's levels of self-regulation (Perry et al., 2002), selfefficacy (Alqurashi, 2016), self-direction, persistence, resilience, and perseverance. For example, students with high self-efficacy use cognitive and metacognitive strategies to do difficult tasks (Dembo $\&$ Eaton, 2000). On the other hand, students with low self-efficacy often fail to self-regulate and end up procrastinating (Klassen et al., 2008; Jungert \& Rosander, 2010). An important task will most likely motivate students to use their cognitive, meta-cognitive, and effort regulation skills such as setting up goals, planning, organizing, and monitoring progress, to achieve it (Pintrich \& DeGroot, 1990). Problem-based learning (PBL), can be used by teachers to support the development of effort regulated learning (Karabulut, 2002).

Peer learning, on the other hand, is a form of cooperative or group learning in which students learn from each other through discussion, questions and answers, and other interactive efforts. According to Boud, Cohen, and Sampson (1999), peer learning is "the use of teaching and learning strategies in which students learn with and from each other without the immediate intervention of a teacher" (p.414). Previous research shows that peer learning has connections with self-efficacy (Liem et al., 
2007), self-regulated learning (Brown et al., 2016), and academic achievement (Broadbent \& Poon, 2015).

It is normal behavior for people to seek help from others when they have a problem that they cannot solve (Newman, 2002). In a school context, for example, a student may seek help from peers via collaborative learning and such an action is perfectly normal and acceptable to prevent failure (Golestaneh \& Askari, 2013). In one study (Liu et al., 2008), help-seeking was found to be associated with improving course grades.

\section{Objectives of the study}

Despite the educational reforms described above under the introduction, secondary students in public schools perform lower in national terminal examinations administered to Year 11 students compared to those in private institutions (see statistics in Ministry of Education, 2017; 2018). The MSLQ (Pintrich, Smith, García, \& McKeachie, 1991a, b; 1993) has been used in research in many different countries and contexts. However, the present study is the first occasion this instrument was utilized in a research setting in Brunei employing a sample of students from government secondary schools. Previous research indicated that there were gender differences in academic achievement among students in the Brunei government education system (Metussin, 2015). Also, the annual government education statistics suggested that other differences in students' achievement might be attributed to learners' differences in age, educational level, and school attended (see Ministry of Education, 2017; 2018). Based on these observations, the present study had two main goals. First, to determine the differences in the participants' MSLQ scores by gender, age, educational level, and school attended. The findings of the present study were expected to have implications on the way the students learn, cope, and develop academically within the government secondary school phase in Brunei. Second, using the obtained results, the current study aimed to identify the patterns of the differences emerging from the research outcomes. Overall, the results of the study were expected to provide further hints, clues, and insights about the educational, psychological, and counselling interventions students may need to fully benefit from the Brunei government secondary school system.

\section{METHOD}

\section{Design}

A field survey design was adopted to observe, compare and contrast the participants' scores obtained from an administration of the Motivated Strategies for Learning Questionnaire, MSLQ (Pintrich, Smith, García, \& McKeachie, 1991a, b; 1993). One principal advantage of this research design is that data were easily and quickly collected from a selected sample of the target population and schools at a single given point in time. This benefit was not available with other survey designs (e.g. postal, online, telephone, cross-sectional, and longitudinal). However, the design's main disadvantage was that the cause-effect relationship of variables investigated could not be established as the strategy was not interventional or experimental. Despite this drawback, the study could yield helpful findings useful in future research.

\section{Participants}

The study used a random sample of 310 Bruneian secondary students representing both genders from three randomly chosen government schools. The participants differed by gender, age, educational level, and school attended as per the research objectives of the study. Selected demographic characteristics of the participants used in the current study are presented in Table 1. Both the participants and schools were chosen using the simple random selection technique. There are many students in Years 7-11 and many government secondary schools throughout Brunei (see Ministry of Education, 2017; 2018). However, the researchers estimated that there were on average five classes 
with approximately 20 students within each Year-level (7-11) at every selected school thereby giving a composite total of 500 students per school or 1, 500 students for all three schools. All students in each selected class were administered the MSLQ instrument. There were no other inclusion criteria. The investigators were aware of common methods of bias when using self-reports in research (Podsakoff et al., 2003; Norton, 2017; Fuller et al., 2016). Given this, we checked all the completed questionnaire protocols for evidence of non-response bias, central tendency error, and extremity response bias and found none. As a result of this, no recruited participant was excluded. According to Krejcie and Morgan's (1970) table of population numbers and required sample sizes, the randomly selected sample $(n=310)$ for the current study was adequate to compute stable statistics at alpha $=0.05$ for an estimated population of 1,500. Because the sample of students and schools used represented only a small fraction of Years 7-11 students in three secondary schools, out of so many in the whole of Brunei (see Ministry of Education, 2017; 2018), the results were generalized only to Years 7-11 students in the three participating schools.

Table 1

Sample demographic information $(\mathrm{N}=310)$

\begin{tabular}{llll}
\hline Variable & Category & Frequency & Percent \\
\hline Gender & Females & 174 & 56.1 \\
\hline Age & Males & 136 & 43.9 \\
\hline & 12 & 20 & 6.5 \\
\hline & 13 & 58 & 18.7 \\
\hline 14 & 60 & 19.4 \\
\hline Education & 15 & 82 & 26.5 \\
\hline & 16 & 60 & 19.4 \\
\hline & 17 & 30 & 9.7 \\
\hline & Form 1 (Year 7) & 50 & 16.1 \\
\hline & Form 2 (Year 8) & 52 & 16.8 \\
\hline School & Form 3 (Year 9) & 50 & 16.1 \\
\hline & Form 4 (Year 10) & 105 & 33.9 \\
\hline & Form 5 (Year 11) & 53 & 17.1 \\
\hline & School 1 & 50 & 16.1 \\
\hline & School 2 & 207 & 66.8 \\
\hline
\end{tabular}

\section{Instruments}

The Motivated Strategies for Learning Questionnaire, MSLQ (Pintrich, Smith, García, \& McKeachie, 1991a, b; 1993) used in the present study has 81 self-report 5-point Likert items of which 31 measure motivation for learning (students' goals, values, beliefs in their skills to succeed, and anxiety) and 50 assess learning strategies (31 items regarding students' use of cognitive and metacognitive strategies and 19 concerning the management of different resources). The 81 items are divided into 15 subscales - six for motivation, and nine for learning strategies. In the present study, the variables investigated and evaluated were the same and kept constant across groups and time. Regarding motivational aspects, the MSLQ enables the measuring of internal and external orientations, task value, control of learning beliefs, self-efficacy for learning and performance, and test anxiety. In learning strategies, the MSLQ assesses the constructs of rehearsal, elaboration, organization, critical thinking, and metacognitive self-regulation. Negatively stated items were reversed when scoring. The subscales' descriptive statistics and reliability are presented in Table 2. All the subscales were reliable for use in Brunei. The MSLQ has been validated and used many times. The reliability indices obtained in the current study resemble those obtained by previous studies (e.g. Duncan \& McKeachie, 2005). 
Table 2

Reliability of the MSLQ subscales $(\mathrm{N}=310)$

\begin{tabular}{llllll}
\hline Subscale & Items & Mean & SEmean & SD & Alpha \\
\hline Test Anxiety & 5 & 24.170 & 0.326 & 5.726 & 0.615 \\
\hline Critical Thinking & 5 & 23.660 & 0.272 & 4.774 & 0.652 \\
\hline Time and Study Environment Management & 8 & 35.610 & 0.347 & 6.121 & 0.647 \\
\hline Internal Motivation & 4 & 20.060 & 0.210 & 3.720 & 0.614 \\
\hline External Motivation & 4 & 23.520 & 0.227 & 3.934 & 0.725 \\
\hline Self-efficacy for Learning and Performing & 8 & 38.730 & 0.394 & 6.924 & 0.792 \\
\hline Task Value & 7 & 35.430 & 0.280 & 5.255 & 0.724 \\
\hline Control of Learning Beliefs & 5 & 27.530 & 0.247 & 4.476 & 0.672 \\
\hline Rehearsal & 5 & 25.170 & 0.287 & 5.067 & 0.660 \\
\hline Elaboration & 7 & 34.580 & 0.343 & 6.032 & 0.678 \\
\hline Organization & 5 & 24.180 & 0.289 & 5.094 & 0.648 \\
\hline Metacognitive Self-regulation & 12 & 55.770 & 0.506 & 8.939 & 0.715 \\
\hline Effort Regulation & 5 & 22.860 & 0.257 & 4.540 & 0.683 \\
\hline Peer Learning & 4 & 19.150 & 0.227 & 4.008 & 0.650 \\
\hline Help Seeking & 5 & 22.920 & 0.245 & 4.338 & 0.617 \\
\hline
\end{tabular}

The convergence and divergence validity of the MSLQ subscales in the present study were determined by inter-subscale Pearson correlations presented in Table 3. For example, rehearsal and elaboration had adequate convergence validity $[\mathrm{r}(310)=0.688, \mathrm{p}<.01]$, and the two domains were conceptually related or largely two sides of the same coin sharing approximately $50 \%$ common variance. On the contrary, test anxiety and effort regulation had sufficient divergence or discriminant validity because they were conceptually distinct and different domains measuring two unrelated attributes $[\mathrm{r}(310)=-$ $0.043, \mathrm{p}>.05]$. Paired variables with a common variance $\geq 50 \%$ demonstrated convergence (concurrent) validity while those with $<50 \%$ exhibited divergence (discriminant) validity. 
Table 3

Validity of the MSLQ subscales by inter-scale correlations $(\mathrm{N}=310)$

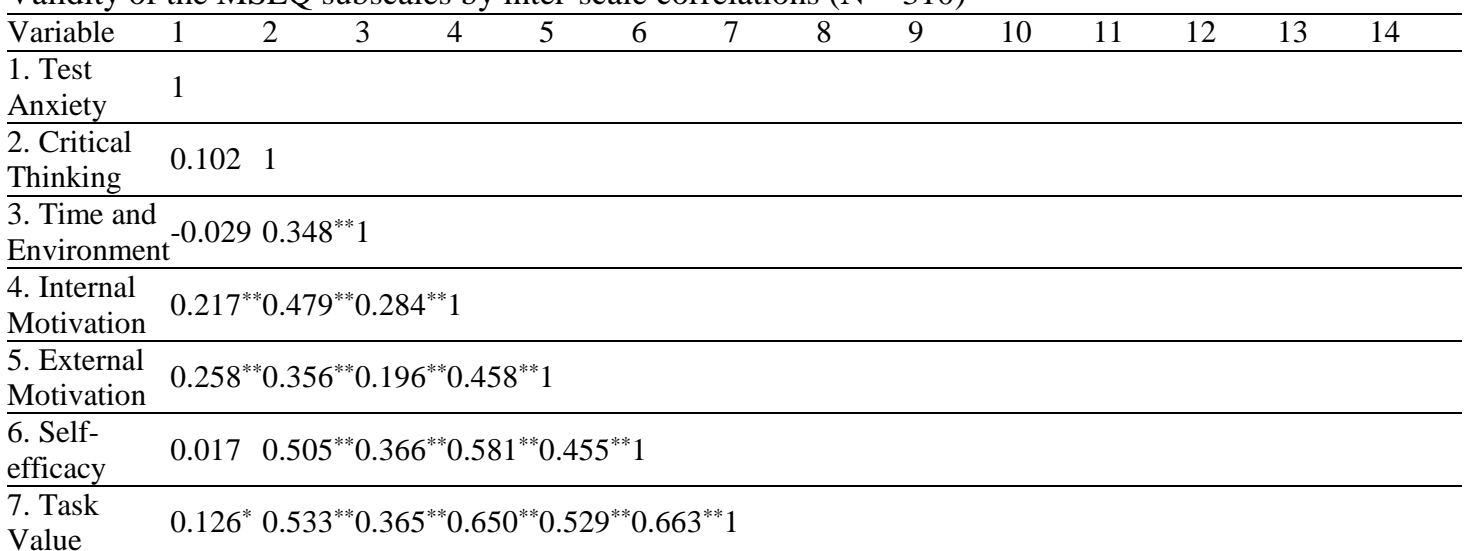

\begin{tabular}{l}
$\begin{array}{l}\text { 8. Learning } 0.318^{* * *} 0.392^{* *} 0.186^{* *} 0.417^{* *} 0.565^{* *} 0.392^{* *} 0.548^{* *} 1 \\
\text { Beliefs }\end{array}$ \\
\hline 9. Rehearsal $0.0950 .599^{* *} 0.434^{* *} 0.443^{* *} 0.413^{* *} 0.512^{* *} 0.549^{* *} 0.419^{* *} 1$ \\
\hline Elaboration $0.166^{* *} 0.688^{* *} 0.410^{* *} 0.428^{* *} 0.331^{* *} 0.443^{* * *} 0.479^{* *} 0.421^{* *} 0.688^{* *} 1$
\end{tabular}

\begin{tabular}{|c|c|}
\hline $\begin{array}{l}11 . \\
\text { Organizatiol }\end{array}$ & $0.116^{*} 0.520^{* *} 0.455^{* *} 0.458^{* *} 0.366^{* *} 0.500^{* * *} 0.509^{* * *} 0.385^{* *} 0.629^{* * *} 0.611^{* * *} 1$ \\
\hline $\begin{array}{l}\text { 12. Self- } \\
\text { regulation }\end{array}$ & $0.110 \quad 0.625^{* *} 0.515^{* *} 0.511^{* *} 0.396^{* *} 0.539^{* * *} 0.582^{* *} 0.431^{* *} 0.633^{* *} 0.640^{* *} 0.551^{* *} 1$ \\
\hline $\begin{array}{l}\text { 13. Effort } \\
\text { Regulation }\end{array}$ & $-0.0430 .407^{* *} 0.406^{* *} 0.303^{* *} 0.293^{* *} 0.317^{* * *} 0.339^{* *} 0.236^{* *} 0.536^{* *} 0.462^{* *} 0.367^{* *} 0.473^{* *} 1$ \\
\hline $\begin{array}{l}\text { 14. Peer } \\
\text { Learning }\end{array}$ & $0.155^{* *} 0.503^{* *} 0.287^{* *} 0.453^{* *} 0.416^{* *} 0.491^{* *} 0.529^{* *} 0.486^{* *} 0.489^{* *} 0.517^{* *} 0.398^{* *} 0.503^{* *} 0.304^{* * *} 1$ \\
\hline $\begin{array}{l}\text { 15. Help } \\
\text { Seeking }\end{array}$ & $0.070 \quad 0.221^{* * *} 0.332^{* * *} 0.115^{*} 0.185^{* *} 0.086 \quad 0.160^{* * *} 0.306^{* * *} 0.249^{* *} 0.334^{* *} 0.160^{* *} 0.240^{* * *} 0.236^{* * *} 0.384^{* *}$ \\
\hline
\end{tabular}

\section{Procedures}

Permission to collect data was obtained from SHBIE at UBD. Also, heads of selected secondary schools in the MOE consented to the data collection request. Before collecting the data, selected participants were briefed about the purposes of the study and ethical conditions for being involved (such as confidentiality, anonymity, privacy, protection from harm, and voluntary participation). Only those participants who, without coercion voluntarily agreed to participate in the study, were eventually recruited and requested to complete the questionnaire (MSLQ). The study did not receive any research grants.

\section{Data Analysis}

The demographic variables were mainly analysed at the item level. The MSLQ items were scored as per instructions in the scale's technical manual. Negative items of the MSLQ were reversed when scoring the instrument. Because the MSLQ is a multidimensional inventory, it was analysed at the subscale level to address the objectives of the study. Descriptive statistics (mean scores, standard deviations, frequencies, and percentages) and inferential statistics (Pearson correlations, independent groups T-tests, and One-Way ANOVA) were used for data analysis. A significance level of 5\% (two- 
tailed) and effect-sizes were used to make decisions and conclusions regarding the findings on the research objectives. The 5\% significance level was chosen because it was liberal (neither too high / stringent nor too low / lenient) to commit Type I and Type II errors, respectively). The Statistical Package for the Social Sciences (SPSS) Version 22 was used for performing the data analysis.

\section{FINDINGS}

\section{Differences by gender}

In terms of gender, significant differences were obtained on seven MSLQ variables (test anxiety, external motivation, control of learning beliefs, rehearsal, organization, self-regulation, and effort regulation) as shown by descriptive statistics, independent groups t-test values, and effect sizes in Table 4. Incidentally, females scored significantly higher on all these variables than males and the differences had low to moderate effect sizes. However, these are overall gender differences for the whole group $(\mathrm{N}=310)$. Gender differences were not investigated by age, education, and school in the current study and this is what future research should do to confirm or disconfirm this pattern and trend.

Table 4

Differences in MSLQ scores by gender $(\mathrm{N}=310)$

\begin{tabular}{|c|c|c|c|c|c|c|c|c|}
\hline Variable & Gender & $\mathrm{n}$ & Mean & $\mathrm{SD}^{\mathrm{a}}$ & SEmean $^{\mathrm{b}}$ & $\mathrm{T}(\mathrm{df}=308)$ & Sig & $\mathrm{ES}^{\mathrm{c}}$ \\
\hline \multirow[t]{2}{*}{ Test Anxiety } & Females & 174 & 25.310 & 5.502 & 0.417 & 4.102 & $0.000 * *$ & 0.052 \\
\hline & Males & 136 & 22.676 & 5.745 & 0.492 & & & \\
\hline \multirow[t]{2}{*}{ Critical Thinking } & Females & 174 & 23.729 & 4.839 & 0.366 & 0.231 & 0.818 & 0.000 \\
\hline & Males & 136 & 23.602 & 4.769 & 0.408 & & & \\
\hline \multirow[t]{2}{*}{ Time and Environment $\mathrm{Mgt}^{\mathrm{d}}$} & Females & 174 & 36.005 & 6.121 & 0.464 & 1.112 & 0.267 & 0.004 \\
\hline & Males & 136 & 35.227 & 6.099 & 0.523 & & & \\
\hline \multirow[t]{2}{*}{ Internal Motivation } & Females & 174 & 20.293 & 3.596 & 0.272 & 1.458 & 0.146 & 0.007 \\
\hline & Males & 136 & 19.676 & 3.815 & 0.327 & & & \\
\hline \multirow[t]{2}{*}{ External Motivation } & Females & 174 & 24.408 & 3.350 & 0.254 & 4.963 & $0.000 * *$ & 0.074 \\
\hline & Males & 136 & 22.213 & 4.436 & 0.380 & & & \\
\hline \multirow[t]{2}{*}{ Self-efficacy for Learning } & Females & 174 & 38.902 & 6.270 & 0.475 & 0.432 & 0.666 & 0.001 \\
\hline & Males & 136 & 38.558 & 7.727 & 0.662 & & & \\
\hline \multirow[t]{2}{*}{ Task Value } & Females & 174 & 31.965 & 4.686 & 0.355 & 0.849 & 0.397 & 0.002 \\
\hline & Males & 136 & 31.485 & 5.253 & 0.450 & & & \\
\hline \multirow[t]{2}{*}{ Control of Learning Beliefs } & Females & 174 & 28.379 & 3.939 & 0.298 & 3.932 & $0.000 * *$ & 0.048 \\
\hline & Males & 136 & 26.463 & 4.633 & 0.397 & & & \\
\hline \multirow[t]{2}{*}{ Rehearsal } & Females & 174 & 26.023 & 5.039 & 0.382 & 3.500 & $0.001 * *$ & 0.038 \\
\hline & Males & 136 & 24.029 & 4.895 & 0.419 & & & \\
\hline \multirow[t]{2}{*}{ Elaboration } & Females & 174 & 35.086 & 5.720 & 0.433 & 1.758 & 0.080 & 0.010 \\
\hline & Males & 136 & 33.875 & 6.385 & 0.547 & & & \\
\hline \multirow[t]{2}{*}{ Organization } & Females & 174 & 25.074 & 4.948 & 0.375 & 3.652 & $0.000 * *$ & 0.041 \\
\hline & Males & 136 & 22.985 & 5.064 & 0.434 & & & \\
\hline \multirow[t]{2}{*}{ Self-regulation } & Females & 174 & 56.701 & 9.249 & 0.701 & 2.179 & $0.030^{*}$ & 0.015 \\
\hline & Males & 136 & 54.492 & 8.324 & 0.713 & & & \\
\hline \multirow[t]{2}{*}{ Effort regulation } & Females & 174 & 23.637 & 4.499 & 0.341 & 3.452 & $0.001 * *$ & 0.037 \\
\hline & Males & 136 & 21.875 & 4.412 & 0.378 & & & \\
\hline \multirow[t]{2}{*}{ Peer Learning } & Females & 174 & 19.465 & 3.730 & 0.282 & 1.547 & 0.123 & 0.008 \\
\hline & Males & 136 & 18.757 & 4.317 & 0.370 & & & \\
\hline \multirow[t]{2}{*}{ Help Seeking } & Females & 174 & 23.097 & 4.188 & 0.317 & 0.820 & 0.413 & 0.002 \\
\hline & Males & 136 & 22.691 & 4.510 & 0.386 & & & \\
\hline
\end{tabular}

$* \mathrm{p}<.05$ (two-tailed)

$* * \mathrm{p}<.01$ (two-tailed)

${ }^{\text {aSD }}=$ Standard deviation

${ }^{\mathrm{b}} \mathrm{SEmean}=$ Standard error of the mean

${ }^{\mathrm{c}} \mathrm{ES}=$ Effect size

${ }^{\mathrm{d}} \mathrm{Mgt}=$ Management 


\section{Differences by age}

The six age cohorts (12-17) differed significantly on six of the 15 MSLQ subscales (critical thinking, time and study environment management, internal motivation, external motivation, rehearsal, and effort regulation) as indicated by One Way ANOVA F-test values and effect sizes in Table 5. On each of these six variables, the sources of the significant differences were examined by mean difference (MD) scores using Tukey HSD multiple comparisons. On critical thinking, 17-year olds outperformed the 12-year olds $(\mathrm{MD}=5.152, \mathrm{p}<.01)$. Students aged 14 scored significantly higher on time and study environment management than the peers aged $16(\mathrm{MD}=5.152, \mathrm{p}<.01)$. For internal motivation, the youngest students in Year 7 (Form 1) scored significantly higher than their older counterparts aged: 13 $(\mathrm{MD}=3.089, \mathrm{p}<.05) ; 15(\mathrm{MD}=3.363, \mathrm{p}<.05) ; 16(\mathrm{MD}=2.966, \mathrm{p}<.05)$; and $17(\mathrm{MD}=3.726, \mathrm{p}<$ $.05)$. With regard to external motivation, students aged 12 had significant scores than those aged 14 $(\mathrm{MD}=3.200, \mathrm{p}<.05)$ and $16(\mathrm{MD}=3.250, \mathrm{p}<.05)$. Rehearsal registered only one significant difference for which participants aged 12 scored higher than those aged $17(\mathrm{MD}=5.780, \mathrm{p}<.01)$. We obtained four significant age-based differences on effort regulation where (on all of them) students aged 12 scored higher than those aged: $13(\mathrm{MD}=3.475, \mathrm{p}<.05) ; 15(\mathrm{MD}=4.224, \mathrm{p}<.01) ; 16(\mathrm{MD}=$ $5.266, \mathrm{p}<.0)$; and $17(\mathrm{MD}=5.004, \mathrm{p}<.01)$.

Table 5

Differences in MSLQ scores by age $(\mathrm{N}=310)$

\begin{tabular}{|c|c|c|c|c|c|}
\hline Variable & $\begin{array}{l}\text { SS Between (Within) } \\
\text { groups }\end{array}$ & $\begin{array}{l}\text { MS Between } \\
\text { (Within) groups }\end{array}$ & $\begin{array}{l}\mathrm{F}(\mathrm{df}=5 \\
309)\end{array}$ & Sig. & $\mathrm{b}^{2}$ \\
\hline Test Anxiety & $134.328(10088.240)$ & $22.388(33.295)$ & 0.672 & 0.681 & 0.013 \\
\hline Critical Thinking & $375.931(6748.162)$ & $62.655(22.271)$ & 2.813 & $0.011 * *$ & 0.053 \\
\hline $\begin{array}{l}\text { Time and Study Environment } \\
\text { Management }\end{array}$ & $622.326(10928.783)$ & $103.721(36.069)$ & 2.876 & $0.010 * *$ & 0.054 \\
\hline Internal Motivation & $211.538(4021.304)$ & $35.256(13.272)$ & 2.657 & $0.016^{*}$ & 0.050 \\
\hline External Motivation & $198.407(4768.160)$ & $33.068(15.737)$ & 2.101 & $0.053^{*}$ & 0.040 \\
\hline $\begin{array}{l}\text { Self-efficacy for Learning and } \\
\text { Performing }\end{array}$ & $487.765(14384.109)$ & $81.294(47.472)$ & 1.712 & 0.118 & 0.033 \\
\hline Task Value & $233.546(7309.821)$ & $38.924(24.125)$ & 1.613 & 0.143 & 0.031 \\
\hline Control of Learning Beliefs & $189.427(5673.609)$ & $31.571(18.725)$ & 1.686 & 0.124 & 0.032 \\
\hline Rehearsal & $418.766(7514.408)$ & $69.794(24.800)$ & 2.814 & $0.011 * *$ & 0.053 \\
\hline Elaboration & $360.384(10918.184)$ & $60.064(36.034)$ & 1.667 & 0.129 & 0.032 \\
\hline Organization & $97.194(7934.060)$ & $16.199(26.185)$ & .619 & 0.715 & 0.012 \\
\hline Metacognitive Self-regulation & $979.057(23549.720)$ & $163.176(77.722)$ & 2.099 & 0.053 & 0.040 \\
\hline Effort Regulation & $507.207(5861.102)$ & $84.535(19.344)$ & 4.370 & $0.000 * *$ & 0.080 \\
\hline Peer Learning & $108.208(4854.360)$ & $18.035(16.021)$ & 1.126 & 0.347 & 0.022 \\
\hline Help Seeking & $159.153(5635.831)$ & $26.526(18.600)$ & 1.426 & 0.204 & 0.027 \\
\hline
\end{tabular}

$* \mathrm{p}<.05$ (two-tailed)

$* * \mathrm{p}<.01$ (two-tailed)

\section{Differences by educational level}

The five educational level groups (Year 7-Year 11) differed significantly on seven factors (critical thinking, time and study environment management, external motivation, rehearsal, metacognitive selfregulation, effort regulation, and help-seeking) as illustrated by One Way ANOVA F-test values and effect sizes in Table 6. Year 11 students scored significantly higher on critical thinking than those in both Year $7(\mathrm{MD}=2.717, \mathrm{p}<.05)$ and Year $9(\mathrm{MD}=3.297, \mathrm{p}<.05)$. Three significant differences were obtained on time and study environment management variables. Year 10 students scored significantly higher on this variable than Year $7(\mathrm{MD}=2.814, \mathrm{p}<.05)$ and Year $9(\mathrm{MD}=5.194, \mathrm{p}<$ .01) students. Besides, Year 11 students also scored significantly higher on this variable than Year 9 
students $(\mathrm{MD}=3.276, \mathrm{p}<.05)$. The Year 10 students were also stronger on external motivation than Year 7 students $(\mathrm{MD}=2.444, \mathrm{p}<.05)$. Year 9 students scored highest on four variables (rehearsal, metacognitive self-regulation, effort regulation, and help-seeking). On rehearsal variable, the Year 9s beat Year 10s $(\mathrm{MD}=2.554, \mathrm{p}<.05)$ and Year 11s $(\mathrm{MD}=3.398, \mathrm{p}<.05)$. The Year 9s also outperformed the Year 8s $(\mathrm{MD}=2.716, \mathrm{p}<.05)$, Year 10s $(\mathrm{MD}=3.978, \mathrm{p}<.01)$, and Year 11s $(\mathrm{MD}=$ $3.215, \mathrm{p}<.05)$ on the metacognitive self-regulation subscale. The three significant differences on the effort regulation subscale were attributed to Year 9s being higher scorers compared to Year 7s $(\mathrm{MD}=$ $2.760, \mathrm{p}<.05)$, Year 10s $(\mathrm{MD}=3.006, \mathrm{p}<.05)$, and Year 11s $(\mathrm{MD}=3.102, \mathrm{p}<.05)$. Concerning the help-seeking variable, the significant difference was accounted for by Year 9s scoring much higher than Year 11s $(\mathrm{MD}=3.847, \mathrm{p}<.05)$.

Table 6

Differences in MSLQ scores by educational level $(\mathrm{N}=310)$

\begin{tabular}{|c|c|c|c|c|c|}
\hline Variable & $\begin{array}{l}\text { SS Between (Within) } \\
\text { groups }\end{array}$ & $\begin{array}{l}\text { MS Between } \\
\text { (Within) groups }\end{array}$ & $\begin{array}{l}F(\mathrm{df}=4, \\
309)\end{array}$ & Sig. & $\mathrm{b}^{2}$ \\
\hline Test Anxiety & $311.838(9910.730)$ & $77.959(32.494)$ & 2.399 & 0.056 & 0.031 \\
\hline Critical Thinking & $325.185(6798.908)$ & $81.296(22.292)$ & 3.647 & $0.006 * *$ & 0.046 \\
\hline $\begin{array}{l}\text { Time and Study Environment } \\
\text { Management }\end{array}$ & $964.580(10586.530)$ & $241.145(34.710)$ & 6.947 & $0.000 * *$ & 0.084 \\
\hline Internal Motivation & $90.131(4142.710)$ & $22.533(13.583)$ & 1.659 & 0.159 & 0.021 \\
\hline External Motivation & $203.978(4762.590)$ & $50.994(15.615)$ & 3.266 & $0.012 * *$ & 0.041 \\
\hline $\begin{array}{l}\text { Self-efficacy for Learning and } \\
\text { Performing }\end{array}$ & $328.336(14543.538)$ & $82.084(47.684)$ & 1.721 & 0.145 & 0.022 \\
\hline Task Value & $121.111(7422.257)$ & $30.278(24.335)$ & 1.244 & 0.292 & 0.016 \\
\hline Control of Learning Beliefs & $37.446(5825.589)$ & $9.362(19.100)$ & 0.490 & 0.743 & 0.006 \\
\hline Rehearsal & $483.775(7449.400)$ & $120.944(24.424)$ & 4.952 & $0.001 * *$ & 0.061 \\
\hline Elaboration & $276.329(11002.238)$ & $69.082(36.073)$ & 1.915 & 0.108 & 0.025 \\
\hline Organization & $127.658(7903.597)$ & $31.914(25.913)$ & 1.232 & 0.297 & 0.016 \\
\hline Metacognitive Self-regulation & $795.388(23733.390)$ & $198.847(77.814)$ & 2.555 & $0.039 *$ & 0.032 \\
\hline Effort Regulation & $999.872(5368.438)$ & $249.968(17.601)$ & 14.202 & $0.000 * *$ & 0.157 \\
\hline Peer Learning & $58.760(4903.808)$ & $14.690(16.078)$ & 0.914 & 0.456 & 0.012 \\
\hline Help Seeking & $406.453(5388.531)$ & $101.613(17.667)$ & 5.751 & $0.000 * *$ & 0.070 \\
\hline
\end{tabular}

$* \mathrm{p}<.05$ (two-tailed)

$* * \mathrm{p}<.01$ (two-tailed)

\section{Differences by school}

At the school level, we obtained significant differences on four variables (critical thinking, external motivation, rehearsal, and effort regulation) as revealed by One Way ANOVA F-test values and effect sizes presented in Table 7. We employed Tukey HSD test to analyze the differences. The two significant differences in critical thinking were caused by School 1 scoring higher than School 3 (MD $=2.717, \mathrm{p}<.05)$ as well as School 2 also scoring much higher than School $3(\mathrm{MD}=2.416, \mathrm{p}<.05)$. School 1 also scored higher than School 2 on both external motivation $(\mathrm{MD}=2.120, \mathrm{p}<.05)$ and effort regulation $(\mathrm{MD}=3.180, \mathrm{p}<.05)$. Furthermore, we noted that School 1 performed higher than School 3 on both rehearsal $(\mathrm{MD}=3.098, \mathrm{p}<.01)$ and effort regulation $(\mathrm{MD}=3.695, \mathrm{p}<.01)$. 
Table 7

Differences in MSLQ scores by school $(\mathrm{N}=310)$

\begin{tabular}{|c|c|c|c|c|c|}
\hline Variable & $\begin{array}{l}\text { aSS Between (Within) } \\
\text { groups }\end{array}$ & $\begin{array}{l}\text { bMS Between } \\
\text { (Within) groups }\end{array}$ & $\begin{array}{l}F(\mathrm{df}=2, \\
309)\end{array}$ & Sig. & c $\mathrm{n}^{2}$ \\
\hline Test Anxiety & $59.748(10162.819)$ & $29.874(33.104)$ & 0.902 & 0.407 & 0.006 \\
\hline Critical Thinking & $272.730(6851.364)$ & $136.365(22.317)$ & 6.110 & $0.002 * *$ & 0.038 \\
\hline $\begin{array}{l}\text { Time and Study Environment } \\
\text { Management }\end{array}$ & $42.278(11508.831)$ & $21.139(37.488)$ & 0.564 & 0.570 & 0.004 \\
\hline Internal Motivation & 41.439 (4191.403) & $20.720(13.653)$ & 1.518 & 0.221 & 0.010 \\
\hline External Motivation & $181.380(4785.188)$ & $90.690(15.587)$ & 5.818 & $0.003 * *$ & 0.037 \\
\hline $\begin{array}{l}\text { Self-efficacy for Learning and } \\
\text { Performing }\end{array}$ & $88.173(14783.701)$ & $44.086(48.155)$ & 0.916 & 0.401 & 0.006 \\
\hline Task Value & $30.872(7512.496)$ & $15.436(24.471)$ & 0.631 & 0.533 & 0.004 \\
\hline Control of Learning Beliefs & $24.613(5838.423)$ & $12.306(19.018)$ & 0.647 & 0.524 & 0.004 \\
\hline Rehearsal & $247.008(7686.166)$ & $123.504(25.036)$ & 4.933 & $0.008 * *$ & 0.031 \\
\hline Elaboration & $120.073(11158.495)$ & $60.036(36.347)$ & 1.652 & 0.193 & 0.011 \\
\hline Organization & $75.910(75.910)$ & $37.955(25.913)$ & 1.465 & 0.233 & 0.009 \\
\hline Metacognitive Self-regulation & $317.701(24211.077)$ & $158.850(78.863)$ & 2.014 & 0.135 & 0.013 \\
\hline Effort Regulation & $463.836(5904.473)$ & $231.918(19.233)$ & 12.058 & $0.000 * *$ & 0.073 \\
\hline Peer Learning & $15.746(4946.822)$ & $7.873(16.113)$ & 0.489 & 0.614 & 0.003 \\
\hline Help Seeking & $81.975(5713.009)$ & $40.987(18.609)$ & 2.203 & 0.112 & 0.014 \\
\hline
\end{tabular}

${ }^{\mathrm{a} S S}=$ Sum of Squares

${ }^{\mathrm{b}} \mathrm{MS}=$ Mean Squares

${ }^{c} \mathrm{D}^{2}=$ Eta Squared (Effect Size)

$* * \mathrm{p}<.01$ (two-tailed)

\section{Patterns, trends, and directions of the differences emerging from the findings}

Overall, we found a total of 41 statistically significant differences. One pattern that was immediately observed consisted of three MSLQ subscales (external motivation, rehearsal, and effort regulation) that had significant differences across all four participants' demographic variables (gender, age, education, and school). These accounted for the majority (20 or 49\%) of all the significant differences detected and feature as the core of the findings. This finding suggested that there was a lot of dependence on external motivation. A trend that visibly emerged was that female (174 or $56 \%$ of the sample) and Year 10s (105 or 34\% of the participants) all scored highest on external motivation than counterparts. Although external motivation (a form of conditioned reinforcement) is important, students should be encouraged to develop, maintain and rely more on internal motivation which is naturally or intrinsically occurring, has deeper roots in the learner, and lasts longer. Most of the significant differences in external motivation were in the positive direction but weak and mainly at $\mathrm{p}<$ .05 level of probability for testing. The relationship between external motivation and internal motivation in the present research was positive and significant but not very high $[\mathrm{r}(310)=0.458, \mathrm{p}<$ $.01]$.

Like external motivation, the rehearsal variable was also important to participants in the current study as evidenced by a high frequency of significant differences (across gender, age, education, and school). Rehearsal, in the present context, refers to different modes of practicing, repetition, and relearning the taught and received knowledge and skills and permits consolidation and mastery of the learned material. In the current study, rehearsal was associated with elaboration $[\mathrm{r}(310)=0.688, \mathrm{p}<$ $.01]$, organization $[\mathrm{r}(310)=0.629, \mathrm{p}<.01]$, and metacognitive self-regulation $[\mathrm{r}(310)=0.633, \mathrm{p}<.01]$. However, mere rehearsal may not be enough to succeed. Students should be encouraged to develop a deeper understanding of the knowledge and skills they acquire to ensure that these are not artificial, 
shaky, and fragile. Another MSLQ variable that registered many significant differences by age, education, and school, was critical thinking (CT). May be due to maturation and more experience of interacting with both the home and school environments, the 17-year-olds were better at CT than the 12-year-olds $(\mathrm{p}<.05)$. Similarly, Year 11 students were also better at CT than both Year 7 and Year 9 peers (all comparisons at $\mathrm{p}=0.05$ level). Of the three schools that participated in the present study, School 3 was the weakest in promoting CT among students compared to School 1 and School 2 (p< $.05)$. Critical thinking, along with creativity and computer literacy, is among the many higher-order skills emphasized by the ongoing school curriculum and assessment reforms in Brunei.

Effort regulation (ER) was the MSLQ factor that registered the highest number of significant differences ( 10 or $24 \%$ in total) in the current study across gender, age, education, and school). The notion of ER might be related to concepts such as persistence, resilience, and perseverance but all these were not investigated in the present study. However, ER was a correlate of metacognitive selfregulation $[\mathrm{r}(310)=0.473, \mathrm{p}<.01]$ and self-efficacy for learning and performance $[\mathrm{r}(310)=0.317, \mathrm{p}<$ $.01]$ in the current study. The mean difference scores on ER were strongest $(\mathrm{p}<.01)$ on comparisons by age (e.g. 12-year olds versus learners aged 15, 16, and 17) as well as on comparisons by schools (e.g. School 1 versus both School 2 and School 3). However, the mean difference scores on ER regarding comparisons by participants' gender and level of education were only significant at $\mathrm{p}=0.05$ level.

\section{DISCUSSION AND IMPLICATIONS}

\section{Differences by gender}

Many relevant previous studies were reviewed to contribute literature to the present investigation. None of the reviewed studies compared and reported the participants' performance on the MSLQ variables by gender. In the present study, females scored much higher than males on seven variables (external motivation, rehearsal, effort regulation, test anxiety, organization, and control of learning beliefs). Of these seven variables, only test anxiety impacts learning negatively (Onwuegbuzie \& Wilson, 2003; Onwuegbuzie, 2004) but can be minimized in various ways (Trifoni \& Shahani, 2011). Test anxiety can be very harmful to students' academic achievement and must be treated to help needy students. Though desirable, extrinsic motivation was weaker compared to internal motivation since it is dependent on external stimuli (Vansteenkiste, 2009) and could be replaced by self-efficacy (Lent et al., 1986; Multon et al., 1991). Concerning rehearsing, past research indicated that students who practice this study strategy were likely to achieve academically (Bıyıklı \& Doğan, 2015). Research has also found out that students who effectively control their learning through effort regulation and selfregulation often succeed (Perry et al., 2002). This is also equally true for students who effectively control their positive learning beliefs (Manavipour and Saeedian, 2016) and can organize their work effectively (Simsek \& Balaban, 2010; Gettinger \& Seibert, 2002).

\section{Differences by age}

With 13 significant differences, age was the second main contributor to variations in participants' MSLQ scores for the current study. However, the differences centered around six MSLQ scales only (critical thinking, time and study environment management, internal motivation, external motivation, rehearsal, and effort regulation). Again, none of the reviewed studies compared and reported the participants' performance on the MSLQ variables by age. Also, only three variables (critical thinking, time and study environment management, and internal motivation) were not involved in gender differences discussed above and will briefly be explained here.

Researchers have recognized critical thinking (CT) as a higher-order skill that needs to be included in school curricular and taught to students (Huber et al., 2016; Shpeizer, 2018). To encourage its teaching in schools, various aspects of CT should be included in school assignments, tests, 
examinations, and research projects (Shively et al., 2018). Critical thinking is positively related to selfefficacy (Hyytinen et al., 2018). Research shows that student-centered teaching practices foster the development of CT in students and should be adopted by teachers to promote CT in students of all ages (Shively et al., 2018).

Time management is a useful study strategy in that it helps the student to make full use of the learning time (Macan, 1994) and reduces procrastination (Onwuegbuzie \& Wilson, 2003; Onwuegbuzie, 2004). Besides, a controlled study environment will help the student to reduce unnecessary distractions (Leblebici, 2012) and improve the learner's productivity (Ajala, 2012).

Intrinsic motivation is the internal natural force that energizes a student to want to learn (Ryan and Deci, 2000). Students with high internal motivation are often active and engaged learners (Barry \& King, 2000). A well-resourced supportive learning environment and student-centered teaching are some of the ways a student could be helped to create and maintain internal motivation (Hinde-McLeod \& Reynolds, 2007; Scott, 2010; Valerio, 2012).

\section{Differences by educational level}

The educational level independent variable (IV) had the highest number of significant differences detected in the present study, 15 in total. However, most of them occurred under similar dependent variables reported on the age IV above. The exceptions were metacognitive self-regulation and helpseeking.

Past research has acknowledged that metacognitive self-regulation facilitates learning (Dinsmore et al., 2008; Schunk \& Zimmerman, 2011). Metacognitive self-regulation is a predictor of academic achievement (Sperling et al., 2004). Learners who are high on metacognitive self-regulation have the ability for self-evaluation (Hacker et al., 2009) and self-direction (Dunn et al., 2012). The learner may also engage in a metacognitive talk (Labuhn et al., 2010; Whitebread, 2010; Winne, 2011), a form of thinking aloud. Regarding help-seeking, it is a prosocial strategy that can aid in resolving learning problems (Newman, 2002; Golestaneh \& Askari, 2013). Help-seeking facilitates academic achievement (Liu et al., 2008). The presence of many significant differences across all secondary school educational levels calls for educational and psychological interventions to be provided to atrisk students at each level. Critical thinking is one variable that should be taught at all levels as it seems to develop late (mainly at Year 11 level in the present study).

\section{Differences by school}

The six significant differences reported on the school IV were on MSLQ subscale variables that have already been discussed above (critical thinking, external motivation, rehearsal, and effort regulation). Critical thinking and effort regulation accounted for most of the detected significant differences. It's particularly worth noting that students in two of the three schools scored significantly higher on critical thinking than peers in the other school. This finding implies that interventions to resolve the students' learning problems need to be made both at the individual student level and at the group level as well as at the school level. This should also be the case for the effort regulation DV which was found to be problematic across all the four IVs (gender, age, educational level, and school) investigated in the present study. It might be beneficial for students (especially those with high support needs) if the MSLQ variables were incorporated in the school curricular, teaching, and assessments.

\section{Patterns, trends, and directions of the differences}

One pattern which emerged from the results of the present study was that no significant differences were detected on four subscales of the MSLQ (self-efficacy for learning and performance, task value, elaboration, and peer learning). The reason for this occurrence is not clear in the absence of a 
qualitative interview component with probes. A trend that we noted concerned the critical thinking subscale on which older students with more education (learners in Years 10-11) scored significantly higher than younger peers with less education (learners in years 7-9). It appeared that the onset of critical thinking ability is facilitated by maturity and more experience in life. The internal motivation was most prevalent in younger Year 7 students than other counterparts. Again, the reason for this finding is not clear but could be that the younger the learners the more they are naturally curious and want to know many things. Test anxiety tended to affect more females than males and this should be addressed by educational and psychological interventions to reduce it. Besides, students who lack effort regulation skills could also benefit from school counselling.

\section{CONCLUSION}

Concerns about the implementation of the ongoing educational reforms (inclusion, curriculum, and examinations) and low performance of students in government secondary schools compared to those in private institutions necessitated the present study. Based on the outcomes of the current study, many issues need to be addressed. The teaching of critical thinking needs to be emphasized in secondary schools. Females are the most prone to test anxiety and those affected need to be identified and provided appropriate interventions. Students need to be helped to develop sustainable academic selfefficacy and internal motivation. Learning strategies such as peer learning and help-seeking need to be brought to the awareness of all students in schools. Apart from test anxiety, students should score high on all the other 14 MSLQ variables. Teachers and school psychologists should identify variables on which students scored too low (by gender, age, educational level, and school attended) on the MSLQ test (other than test anxiety) in the present study and determine how students could be helped to improve on those skills. We recommend that further similar but large-scale MSLQ-based studies in Brunei context should use more robust statistics such as confirmatory factor analysis (CFA) with qualitative probes to obtain additional insights.

\section{REFERENCES}

Ajala, E. M. (2012). The Influence of Workplace Environment on Workers' Welfare, Performance, and Productivity. The African Symposium: An Online Journal of the African Educational Research Network, 12(1), 141-149. https://doi.org/ISSN\#TX 6- 342-323

Akimoto, T., Tanabe, S. I., Yanai, T., \& Sasaki, M. (2010). Thermal comfort and productivityEvaluation of workplace environment in a task conditioned office. Building and Environment, 45(1), 45-50.

Alqurashi, E. (2016). Self-efficacy in online learning environments: A literature review. Contemporary Issues in Education Research, 9(1), 45-52. https://doi.org/10.19030/cier.v9i1.954

Bandura, A. (1977). Self-efficacy: Toward a unifying theory of behavioral change. Psychological Review, 84, 191-215.

Bandura, A. (1997). Self-Efficacy: The Exercise of Control. New York, NY: Freeman.

Banks, J. A. (1995). Multicultural education: Historical development, dimensions, and practice. In J. A. Banks and C.A.M Banks (Eds). Handbook of research on multicultural education (pp.617-627). New York, NY: Macmillan.

Barry, K. \& King, L. (2000). Beginning Teaching and Beyond (3rd ed). Towoomba, NSW: Social Science Press.

Biyıklı, C. \& Doğan, N. (2015). The Effects of Learning Strategies Used for Rehearsal on the Academic Success. Education and Science, 40(181). 311-327. 
Boud, D., Cohen, R., \& Sampson, J. (1999). Peer Learning and Assessment. Assessment and Evaluation in Higher Education, 24(4), 413-426.

Broadbent, J. \& Poon, W. L. (2015) Self-regulated learning strategies \& academic achievement in online higher education learning environments: A systematic review. Internet and Higher Education, 27, 1-13. http://dx.doi.org/10.1016/j.iheduc.2015.04.007

Brown, G. T. L., Peterson, E. R., \& Yao, E. S. (2016). Student conceptions of feedback: Impact on self-regulation, self-efficacy, and academic achievement. British Journal of Educational Psychology, 86(4), 606-629. doi:10.1111/bjep.12126

Cassady, J. C., \& Johnson, R. E. (2002). Cognitive test anxiety and academic performance. Contemporary Educational Psychology, 27(2), 270-295. https://doi.org/10.1006/ceps.2001.1094

Culler, R. E., \& Holahan, C. J. (1980). Test anxiety and academic performance: The effects of studyrelated behaviors. Journal of Educational Psychology, 72(1), 16-20. https://doi.org/10.1037/00220663.72.1.16

Dembo, M. H., \& Eaton, M. J. (2000). Self-regulation of academic learning in middle-level schools. The Elementary School Journal, 100, 473-490.

Dinsmore, D. L., Alexander, P. A., \& Loughlin, S. M. (2008). Focusing the conceptual lens on metacognition, self-regulation, and self-regulated learning. Educational Psychology Review, 20(4), 391-409.

Dunn, K. E., Lo, W. J., Mulvenon, S. W., \& Sutcliffe, R. (2012). Revisiting the motivated strategies for learning questionnaire: A theoretical and statistical re-evaluation of the metacognitive selfregulation and effort regulation subscales. Educational and Psychological Measurement, 72(2), 312331.

Dweck, C. (1999). Self-theories: The role in motivation, personality, and development. Philadelphia: Taylor \& Francis

Eccles, J., Wigfield, A., \& Schiefele, U. (1998). Motivation to succeed. In W. Damon \& N. Eisenberg (Eds.), Handbook of child psychology, Volume 3: Social, emotional, and personality development, 5th edition (pp. 1017-1095). New York: Wiley.

Garcia, T. (1995). The role of motivational strategies in self-regulated learning. New Directions for Teaching and Learning, 1995(63), 29-42. Doi:10.1002/t1.37219956306

Gettinger, M., \& Seibert, J. K. (2002). Contributions of study skills to academic competence. School Psychology Review, 31(3), 350-365.

Golestaneh, S. M., \& Askari, F. (2013). Help-seeking or help avoidance: Important motivational, personality, and metacognitive antecedents' role in help-seeking and help-avoidance between normal and gifted students. European Online Journal of Natural and Social Sciences, 2(3), 3403-3410.

Hinde-McLeod, J. \& Reynolds, R. (2007). Quality Teaching for Quality Learning: Planning through reflection. Melbourne: Cengage Learning.

Huber, C. R., \& Kuncel, N. R. (2016). Does College Teach Critical Thinking? A Meta-Analysis. Review of Educational Research, 86(2), 431-468. https://doi.org/10.3102/0034654315605917

Hyytinen, H., Tooma, A., Postareff, L. (2018). Unraveling the complex relationship in critical thinking approaches to learning and self-efficacy beliefs among first-year educational Science students. Learning and Individual Differences, 67, 132-142, https://doi.org/10.1016/j.lindif.2018.08.004 
Johnson, G. R., Elson, J. A., Abbot, R., Meiss, G. T., Moran, K., Morgan, J. A., Pasternack, T. L., Zaremba, E., \& McKeachie, W. J. (1991). Teaching tips for users of the Motivated Strategies for Learning Questionnaire (MSLQ). Technical Report No. 91-B-005 Prepared for the National Center for Research to Improve Postsecondary Teaching and Learning (NCRIPTAL), pp 1-46. Ann Arbor, MI: The University of Michigan.

Jungert, T., \& Rosander, M. (2010). Self-efficacy and strategies to influence the study environment. Teaching in Higher Education, 15(6), 647-659.

Karabulut, U. S. (2002). Curricular elements of problem-based learning that cause developments of self-directed learning behaviors among students and its implications on elementary education. Unpublished doctoral dissertation. Knoxville, TN: The University of Tennessee.

Klassen, R. M., Krawchuk, L. L., \& Rajani, S. (2008). Academic procrastination of undergraduates: Low self-efficacy to self-regulate predicts higher levels of procrastination. Contemporary Educational Psychology, 33(4), 915-931.

Labuhn, A. S., Zimmerman, B. J., \& Hasselhorn, M. (2010). Enhancing students' self-regulation and mathematics performance: The influence of feedback and self-evaluative standards. Metacognition and Learning, 5(2), 173-194.

Leblebici, D. (2012). Impact of workplace quality on employee's productivity: a case study of a bank in Turkey. Journal of Business Economics, 1(1), 38-49.

Lent, R. W., Brown, S. D., \& Larkin, K. C. (1986). Self-efficacy in the prediction of academic performance and perceived career options. Journal of Counseling Psychology, 33, 265-269.

Li, Y., Guo, F., Yao, M., Wang, C., \& Yan, W. (2016). The Role of Subjective Task Value in ServiceLearning Engagement among Chinese College Students. Frontiers in Psychology, 23(7), 954. doi:10.3389/fpsyg.2016.00954

Liem, A. D., Lau, S., \& Nie, Y. (2008). The role of self-efficacy, task value, and achievement goals in predicting learning strategies, task disengagement, peer relationship, and achievement outcome. Contemporary Educational Psychology, 33(4), 486-512. doi: http://dx.doi.org/10.1016/j.cedpsych.2007.08.001

Liu, O.L., Jackson, T., Ling, G. (2008). An Initial Field Trial of an Instrument for Measuring Learning Strategies of Middle School Students. ETS Research Reports. Available at: http://www.ets.org/research/contact.html (Last access: Feb. 1st, 2020).

Lynch, D.J. (2010). Motivational Beliefs and Learning Strategies as Predictors of Academic Performance in College Physics. College Student Journal, 44(4), 920-927.

Macan, T. H. (1994). Time management: Test of a process model. Journal of Applied Psychology, 79(3), 381-391. DOI: 10.1037/0021-9010.79.3.381

Mayer, R. E. (1980). Elaboration techniques that increase the meaningfulness of technical text: An experimental test of the learning strategy hypothesis. Journal of Educational Psychology, 72(6), 770784. https://doi.org/10.1037/0022-0663.72.6.770

Metussin, H. (2015). Where are the males? Potential causal factors of the gender gap in higher education in Brunei and implications for educators. A thesis in partial fulfillment of the requirements for the Degree of Doctor of Philosophy. Bandar Seri Begawan: Sultan Hassanal Bolkiah Institute of Education, University of Brunei Darussalam. 
Ministry of Education. (1997). Special Education Policy Guidelines. Bandar Seri Begawan: Unit Pendidikan Khas.

Ministry of Education. (1998). Handbook on Special Education for Primary School Headmasters: Outline of Policies and Procedures Dealing with Special Education. Bandar Seri Begawan: Unit Pendidikan Khas.

Ministry of Education. (2008). Proposed SPN21 curriculum: Draft. Bandar Seri Begawan: Curriculum Development Division,

Ministry of Education. Ministry of Education. (2008). Adhoc Committee on Education Program for Gifted Students. Bandar Seri Begawan: Unit Pendidikan Khas.

Ministry of Education. (2013). Brunei Teacher Standards. Bandar Seri Begawan: Government Printing.

Ministry of Education. (2017). Brunei Darussalam education statistics 2017. Bandar Seri Begawan: Educational Data Management Section, Department of Planning, Development, and Research.

Ministry of Education. (2018). Brunei Darussalam education statistics 2018. Bandar Seri Begawan: Educational Data Management Section, Department of Planning, Development, and Research.

Multon, K. D., Brown, S. D., \& Lent, R. W. (1991). Relation of self-efficacy beliefs to academic outcomes: A meta-analytic investigation. Journal of Counseling Psychology, 38, 30-38.

Newman, R. (2002). How self-regulated learners cop with academic difficulty: The role of adaptive help-seeking. Theory into Practice, 41(2), 132- 138.

Norton, S. J. (2017). Primary mathematics trainee teacher confidence and its relationship to mathematical knowledge. Australian Journal of Teacher Education, 42(2), 47-61. http://dx.doi.org/10.14221/ajte.2017v42n2.4

Onwuegbuzie, A. J., \& Wilson, V. A. (2003). Statistics anxiety: nature, etiology, antecedents, effects, and treatments - a comprehensive review of the literature. Teaching in Higher Education, 8(2), 195209.

Onwuegbuzie, A. J. (2004). Academic procrastination and statistics anxiety. Assessment and Evaluation in Higher Education, 29, 3-19.

Perry, N. E., Vandekamp, K. O., Mercer, L. K., \& Nordby, C. J. (2002). Investigating teacher-student interactions that foster self-regulated learning. Educational Psychologist, 37, 5-15.

Pintrich, P. R., \& De Groot, E. (1990). Motivational and self-regulated learning components of classroom academic performance. Journal of Educational Psychology, 82, 33-40.

Pintrich, P.R., Smith, D.A.F., Garcia, T., \& McKeachie, W.J. (1991a). A Manual for the Use of the Motivated Strategies for Learning Questionnaire (MSLQ). Technical Report No. 91-8-004. The Regents of The University of Michigan, doi:10.1177/0013164493053003024

Pintrich, P. R., Smith, D. A. F., García, T., \& McKeachie, W. J. (1991b). A manual for the use of the Motivated Strategies for Leaning Questionnaire $(M S L Q)$. Ann Arbor: the University of Michigan, National Center for Research to Improve Postsecondary Teaching and Learning.

Pintrich, P. R., Smith, D. A. F., García, T., \& McKeachie, W. J. (1993). Reliability and predictive validity of the Motivated Strategies for Learning Questionnaire (MSLQ). Educational and Psychological Measurement, 53, 801-813. 
Pintrich, P. R. (1999). The role of motivation in promoting and sustaining self-regulated learning. International Journal of Educational Research, 31(6), 459-470. doi:10.1016/S0883-0355(99)00015-4

Podsakoff, P. M., MacKenzie, S. B., Lee, J.-Y., \& Podsakoff, N. P. (2003). Common method biases in behavioral research: A critical review of the literature and recommended remedies. Journal of Applied Psychology, 88(5), 879-903. doi:10.1037/0021-9010.88.5.879

Podsakoff, P. M., MacKenzie, S. B., \& Podsakoff, N. P. (2012). Sources of method bias in social science research and recommendations on how to control it. Annual Review of Psychology, 63(1), 539-569. doi:10.1146/annurev-psych-120710-100452

Ryan, R. M., and Deci, E. L. (2000). Intrinsic and extrinsic motivations: Classic definitions and new directions. Contemporary Educational Psychology, 25, 54-67.

Rotter, J. B. (1966). Generalized expectancies for internal versus external control of reinforcement. Psychological Monographs: General and Applied, 80(1), 1-28. https://doi.org/10.1037/h0092976

Rotter, J. B. (1975). Some problems and misconceptions related to the construct of internal versus external control of reinforcement. Journal of Consulting and Clinical Psychology, 43(1), 56-67. https://doi.org/10.1037/h0076301

Seo, D., \& Taherbhai, H. (2009). Motivational beliefs and cognitive processes in mathematics achievement analyzed in the context of cultural differences: A Korean elementary school example. Asia Pacific Education Review, 10, 193-203.

Simsek, A., \& Balaban, J. (2010). Learning Strategies for successful and unsuccessful students. Contemporary Education Technology, 1(1), 36-45.

Somtsewu, N. (2008). The Application of the Motivated Strategies for Learning Questionnaire (MSLQ) for South Africa. Nelson Mandela Metropolitan University. Retrieved from https://core..ac.uk/download/pdf/145041907.pdf

Scott, T. (2010). Classes are communities of learning. Professional Educator, 9(3), 14-16.

Schunk, D. H., \& Zimmerman, B. (Eds.). (2011). Educational psychology handbook series. Handbook of self-regulation of learning and performance. London: Routledge/Taylor \& Francis Group.

Shively, K., Stith, K. M., \& Rubenstein, L. D. (2018). Measuring What Matters: Assessing Creativity, Critical Thinking, and the Design Process. Gifted Child Today, 41(3), 149-158. https://doi.org/10.1177/1076217518768361

Shpeizer, R. (2018). Teaching critical thinking as a vehicle for personal and social transformation. Research in Education, 100(1), 32-49. https://doi.org/10.1177/0034523718762176

Sperling, R. A., Howard, B. C., Staley, R., \& DuBois, N. (2004). Metacognition and self-regulated learning constructs. Educational Research and Evaluation, 10(2), 117-139.

Sternberg, R.J. \& Williams, W.M. (2002). Educational Psychology. Boston, MA: Allyn \& Bacon.

Tay, B., Unal, M., Kafadar, T. (2016). The Use of Rehearsal Strategies in Social Studies Education Textbooks by Prospective Classroom Teachers. International Journal of Social Science and Education, 6(3). 280-290.

Valerio, K, (2012). Intrinsic motivation in the classroom, Journal of Student Engagement: Education Matters, 2(1), 30-35. Available at: https://ro.uow.edu.au/jseem/vol2/iss1/6 
Weinstein, C. \& Mayer, R. (1986). The Teaching of Learning Strategies. In: Wittrock, M., Ed., Handbook of Research on Teaching, pp. 315-327.New York: Macmillan.

Winne, P. H. (2011). A cognitive and metacognitive analysis of self-regulated learning. In B. J. Zimmerman \& D. H. Schunk (Eds.), Educational psychology handbook series. Handbook of selfregulation of learning and performance (p. 15-32). Routledge/Taylor \& Francis Group.

Whitebread, D. (2010). Play: Metacognition and self-regulation. In P. Broadhead, J. Howard, and E Wood (eds). Play and learning in the early years: From research to practice. (pp. 161-176). London: Sage.

Yoon, K. S., Eccles, J. S., \& Wigfield, A. (1996, April). Self-concept of ability, value, and academic achievement: A test of causal relations. Paper presented at the 1996 Annual Meeting of the American Educational Research Association, New York, NY. Retrieved from http://www.rcgd.isr.umich.edu/garp/articles/eccles96o.pdf. 